\title{
Analisis Perbandingan Tingkat Kesehatan Bank dengan Menggunakan Pendekatan RGEC (Studi pada PT. Bank Mandiri (Persero), Tbk dan PT. Bank Negara Indonesia (Persero), Tbk Periode 2014-2018)
}

\author{
Marissa Putriana, Susi Artati \\ Universitas Batanghari Jambi \\ Correspondence email: marissa.putriana89@gmail.com
}

\begin{abstract}
This research aims to analyse how the health level comparison of PT Bank Mandiri (Persero), Tbk with PT Bank Negara Indonesia (Persero), Tbk using RGEC (Risk Profile, Good Corporate Governance, Earnings, Capital) approach In 20142018. The type of research used is quantitative descriptive research. Research results show the health level of Bank Mandiri and BNI in 2014-2018 overall healthy. Risk Profile Bank Mandiri and BNI bank with the credit risk indicator gained a healthy predicate and with the risk indicators of the liquidity of both banks earned a fairly healthy predicate. Assessment of Good Corporate Governance (GCG) based on Self Assessment showed that Bank Mandiri obtained very good predicate while BNI Bank obtained good predicate. The Earnings assessment of the ROA and NIM ratio analysis and Capital valuation based on the CAR value analysis showed that Bank Mandiri and BNI Bank gained a very healthy predicate.
\end{abstract}

Keywords : The health level of bank, RGEC Method, Risk Profile, GCG, Earnings, Capital

\section{PENDAHULUAN}

Perbankan memiliki peran yang sangat penting dalam perekonomian suatu negara. Bank merupakan lembaga keuangan yang fungsi utamanya adalah menghimpun dana dari masyarakat, menyalurkan dana kepada masyarakat, dan juga memberikan pelayanan dalam bentuk jasa perbankan (Ismail, 2013). Sebagai suatu lembaga yang mengelola dana masayarakat tentu kepercayaan masayarakat adalah suatu hal yang mesti dijaga oleh bank demi keberlangsungan usahanya. Kinerja perbankan yang baik tentu memberikan kepercayaan bagi nasabahnya dalam menempatkan dana yang dimilikinya dengan rasa aman. Kinerja perbankan dapat dilakukan dengan penilaian kesehaan bank. Penilaian kesehatan bank adalah penting untuk menilai bagaimana kondisi kesehatan bank itu sendiri, apakah dalam kondisi sehat atau tidak. Penilaian kesehatan bank akan berguna dalam menerapkan Good Corporate Governance dan untuk menghadapi resiko di masa yang akan datang (PBI No.13/1/PBI/2011). Standar dalam melakukan penilaian kesehatan bank telah ditentukan pemerintah melalui Bank Indonesia. Berdasarkan Peraturan Bank Indonesia Nomor 13/1/PBI/2011 tentang Penilaian tingkat kesehatan bank umum, bank wajib melakukan penilaian tingkat kesehatan dengan menggunakan pendekatan risiko (Risk-based Bank Rating) atau kerap disebut metode RGEC (Risk Profile, Good Corporate Governance, Earnings, Capital). Metode RGEC adalah penilaian kesehatan bank pengganti penilaian bank sebelumnya yaitu metode CAMEL.

Menurut Peraturan Bank Indonesi No. 13/1/PBI/2011, Pasal 7, Penilaian terhadap faktor profil risiko merupakan penilaian terhadap risiko inheren dan kualitas penerapan manajemen risiko dalam operasional Bank yang dilakukan terhadap 8 (delapan) risiko yaitu risiko kredit, risiko pasar, risiko likuiditas, risiko operasional, risiko hukum, risiko stratejik, risiko kepatuhan dan risiko reputasi. Penilaian terhadap faktor GCG merupakan penilaian terhadap manajemen Bank atas pelaksanaan prinsip-prinsip GCG. Penilaian terhadap faktor rentabilitas (earnings) meliputi penilaian terhadap kinerja earnings, sumber-sumber earnings, dan sustainability earnings Bank. Penilaian terhadap faktor permodalan (capital) meliputi penilaian terhadap tingkat kecukupan permodalan dan pengelolaan permodalan. Setiap faktor penilaian Tingkat Kesehatan Bank ditetapkan peringkatnya berdasarkan kerangka analisis yang komprehensif dan terstruktur. Pedoman lebih lengkap diatur dalam Surat Edaran BI No 13/24/DPNP/2011 tanggal 25 oktober 2011 tentang penilaian tingkat kesehatan bank umum. Penelitian terkait tingkat kesehatan bank menggunakan RGEC pernah dilakukan oleh Kartika (2016) dengan melakukan penelitian pada Bank Mandiri dan BCA periode 2011-2013 menunjukkan hasil bahwa secara keseluruhan dapat dikatakan kedua bank adalah bank yang sehat. Anggraini (2015) melakukan analisis kinerja bank konvensional (BRI) dan 
Marissa Putriana dan Susi Artati, Analisis Perbandingan Tingkat Kesehatan Bank dengan Menggunakan Pendekatan RGEC (Studi pada PT. Bank Mandiri (Persero), Tbk dan PT. Bank Negara Indonesia (Persero), Tbk Periode 2014-2018)

bank syariah (BRI Syariah) menggunakan pendekatan RGEC periode 2011-2013, hasil penelitiannya menunjukkan secara keseluruhan kinerja BRI dan BRI Syariah adalah sehat.

\section{METODE}

Jenis penelitian yang digunakan adalah penelitian deskriptif kuantitatif. Sumber data menggunakan data sekunder berupa laporan tahunan Bank Mandiri dan Bank BNI periode 2014-2018 melalui situs website masing-masing bank serta website Bursa Efek Indonesia. Tahapan analisis yang digunakan berdasarkan Surat Edaran Bank Indonesia No. 13/24/DPNP/Tanggal 25 Oktober 2011 tentang Penilaian tingkat kesehatan Bank Umum yaitu menggunakan pendekatan RGEC (Risk Profile, Good Corporate Governance, Earnings dan Capital). Adapun analisis penelitian ini meliputi :

a. Penilaian terhadap pendekatan RGEC, yang terdiri dari (1) Risk Profile (Profil Risiko). Pada penelitian ini penilaian profil risiko diukur dengan dua indikator yaitu risiko kredit dan risiko likuiditas. Risiko kredit menggunakan rumus NPL (Non Performing Loan) dan risiko likuiditas mengunakan rumus LDR (Loan to Deposit Ratio); (2) Good Corporate Governance (GCG). Penilaian atas faktor GCG dimaksudkan untuk menilai bank dalam pelaksanaan prinsip-prinsip GCG yang mengacu kepada kententuan Bank Indonesia mengenai GCG bagi bank umum dengan memperhatikan karakteristik dan kompleksitas usaha bank. Penilaian didasarkan dalam tiga aspek utama yaitu, governance structure, governance process, dan governance ouput. Penilaian diambil berdasarkan Self Assessment bank yang bersangkutan; (3) Earning (Rentabilitas). Analisis rentabilitas pada penelitian ini menggunakan rasio Return on Assets (ROA) dan Net Interest Margin (NIM); dan (4) Capital (Permodalan). Adapun faktor capital penelitian ini dinilai menggunakan Capital Adequacy Ratio (CAR).

b. Analisis tingkat kesehatan bank Melalui pemeringkatan dari masing-masing analisis berdasarkan Peraturan Bank Indonesia No. 13/1PBI/2011 dan Surat Edaran BI No. 13/24/DPN/2011 perihal penilaian tingkat kesehatan bank umum.

\section{HASIL \\ a. Risk Profile \\ Risiko Kredit}

Tabel 1

Rasio Net Performing Loan (NPL)

\begin{tabular}{cccccccc}
\hline \multirow{2}{*}{ Tahun } & NPL $(\%)$ & $\begin{array}{c}\text { Bank Mandiri } \\
\text { Peringkat }\end{array}$ & Predikat & Tahun & NPL (\%) & $\begin{array}{c}\text { Bank BNI } \\
\text { Peringkat }\end{array}$ & Predikat \\
\hline $\mathbf{2 0 1 4}$ & 1,66 & 1 & Sangat Sehat & $\mathbf{2 0 1 4}$ & 2,0 & 2 & Sehat \\
$\mathbf{2 0 1 5}$ & 2,29 & 2 & Sehat & $\mathbf{2 0 1 5}$ & 2,7 & 2 & Sehat \\
$\mathbf{2 0 1 6}$ & 3,96 & 2 & Sehat & $\mathbf{2 0 1 6}$ & 3,0 & 2 & Sehat \\
$\mathbf{2 0 1 7}$ & 3,45 & 2 & Sehat & $\mathbf{2 0 1 7}$ & 2,3 & 2 & Sehat \\
$\mathbf{2 0 1 8}$ & 2,79 & 2 & Sehat & $\mathbf{2 0 1 8}$ & 1,9 & Sangat Sehat \\
\hline
\end{tabular}

Sumber: data olahan

Berdasarkan Tabel 1 di atas dapat diketahui, pada tahun 2014 nilai NPL Bank Mandiri lebih unggul dibandingakan Bank BNI, yaitu berada pada peringkat satu dengan predikat sangat sehat (NPL $<2 \%$ ) dengan nilai rasio sebesar 1,66\%, sedangkan Bank BNI mendapat peringkat dua memperoleh predikat sehat dengan nilai NPL sebesar 2\%. Namun sebaliknya, di tahun 2018 Bank BNI lebih unggul dibanding Bank Mandiri dengan memperoleh predikat sangat sehat dengan NPL sebesar 1,9\% sedangkan Bank Mandiri memiliki NPL sebesar 2,79\% dan berada pada peringkat dua mendapat predikat sehat. Nilai NPL untuk Bank Mandiri pada tahun 2015 mengalami kenaikan menjadi 2,29 \%, kemudian naik kembali pada tahun 2016 menjadi 3,96\%. Penurunan terjadi pada tahun 2017 menjadi 3,45\% dan kemudian turun kembali menjadi 2,79 \%. Sedangkan nilai NPL untuk Bank BNI pada tahun 2015 naik menjadi 2,5\%, kemudian naik kemabali di tahun 2016 menjadi 3\% dan pada tahun 2017 dan 2018 mengalami penurunan dengan nilai masing-masing yaitu 2,3 \% dan 1,9\%. Menurunnya rasio NPL menunjukkan bahwa baiknya pengelolaan risiko kredit oleh kedua bank tersebut. 
Marissa Putriana dan Susi Artati, Analisis Perbandingan Tingkat Kesehatan Bank dengan Menggunakan Pendekatan RGEC (Studi pada PT. Bank Mandiri (Persero), Tbk dan PT. Bank Negara Indonesia (Persero), Tbk Periode 2014-2018)

\section{Risiko Likuiditas}

Tabel 2

Rasio Loan to Deposit Ratio (LDR)

\begin{tabular}{cccccccc}
\hline Tahun & LDR (\%) & $\begin{array}{c}\text { Bank Mandiri } \\
\text { Peringkat }\end{array}$ & Predikat & Tahun & LDR (\%) & $\begin{array}{c}\text { Bank BNI } \\
\text { Peringkat }\end{array}$ \\
\hline $\mathbf{2 0 1 4}$ & 82,86 & 2 & Sehat & $\mathbf{2 0 1 4}$ & 87,8 & 3 & Cukup sehat \\
$\mathbf{2 0 1 5}$ & 87,68 & 3 & Cukup Sehat & $\mathbf{2 0 1 5}$ & 87,8 & 3 & Cukup sehat \\
$\mathbf{2 0 1 6}$ & 86,54 & 3 & Cukup Sehat & $\mathbf{2 0 1 6}$ & 90,4 & 3 & Cukup sehat \\
$\mathbf{2 0 1 7}$ & 88 & 3 & Cukup Sehat & $\mathbf{2 0 1 7}$ & 85,6 & 3 & Cukup sehat \\
$\mathbf{2 0 1 8}$ & 95 & 3 & Cukup Sehat & $\mathbf{2 0 1 8}$ & 88,8 & Cukup sehat \\
\hline
\end{tabular}

Sumber: data olahan

Berdasarkan Tabel 2 di atas pada tahun 2014 Bank Mandiri memiliki LDR yang lebih unggul dibandingkan Bank BNI, yaitu LDR Bank Mandiri mendapat predikat sehat (LDR < 85\%) dimana nilai LDR sebesar $82,86 \%$. Sedangkan untuk Bank BNI mendapat predikat cukup sehat di peringkat tiga dengan LDR sebesar 87,8 \%. Kemudian di tahun berikutnya, 2015 hingga 2018 Bank Mandiri dan Bank BNI berada pada peringkat yang sama yaitu peringkat 3 dengan predikat cukup sehat. Nilai rasio LDR pada bank mandiri tahun 2014 sampai 2018 berfluktuasi, masing-masing 82,86\%, 87,68\%, 86,54\%, 88\%, 95\%. Dari nilai tersebut dapat diartikan bahwa nilai LDR yang dimiliki bank mandiri cukup tinggi atau masuk dalam predikat cukup sehat. Naiknya nilai LDR menaikkan kemungkinan bank tersebut dalam keadaan bermasalah karena semakin tinggi nilai LDR semakin rendah kemampuan likuiditas bank tersebut. Sedangkan untuk bank BNI selisihnya tidak jauh berbeda dengan bank mandiri, dimana bank BNI pada tahun 2014 dan 2015 stagnan dengan nilai 87,8\%, kemudian di tahun 2016 naik menjadi 90,4\% dan mengalami penurunan pada tahun 2017 yaitu 85,6\% dan naik menjadi 88,8\% di tahun 2018. Semakin tinggi nilai LDR mencerminkan semakin rendah kemampuan likuiditas bank, begitupun sebaliknya. Namun, melalui LDR dapat pula digunakan untuk menilai strategi manajemen suatu bank. Manajemen bank yang konservatif biasanya cenderung memiliki LDR yang relatif rendah, sebaliknya manajemen bank yang agresif memiliki LDR yang tinggi aau melebihi batas toleransi (Simorangkir, 2004). Menurut Kasmir (2014), batas aman dari LDR suatu bank adalah sekitar $80 \%$. Namun batas maksimal LDR adalah $110 \%$.

\section{b. Good Corporate Governance (GCG)}

Tabel 3

Good Corporate Governance (GCG) / Self Assesment

\begin{tabular}{cccccc}
\hline \multirow{2}{*}{ Tahun } & \multicolumn{2}{c}{ Bank Mandiri } & \multirow{2}{*}{ Tahun } & Nilai Komposit & Bank BNI \\
& Nilai Komposit & Predikat & & 2 & 2 \\
$\mathbf{2 0 1 4}$ & 1 & Sangat Baik & $\mathbf{2 0 1 4}$ & Baik \\
$\mathbf{2 0 1 5}$ & 2 & Baik & $\mathbf{2 0 1 5}$ & 2 & Baik \\
$\mathbf{2 0 1 6}$ & 1 & Sangat Baik & $\mathbf{2 0 1 6}$ & 2 & Baik \\
$\mathbf{2 0 1 7}$ & 1 & Sangat Baik & $\mathbf{2 0 1 7}$ & Baik \\
$\mathbf{2 0 1 8}$ & 1 & Sangat Baik & $\mathbf{2 0 1 8}$ & 2 & Baik \\
\hline
\end{tabular}

Sumber: data olahan

Penilaian terhadap faktor GCG dengan pendekatan RGEC didasarkan dalam tiga aspek utama yaitu, governance structure, governance process, dan governance ouput. Tabel 3 di atas menunjukkan hasil self assessment dalam pelaksanaan GCG antara Bank Mandiri dan Bank BNI . Hasil self assessment Bank Mandiri dari tahun 2014 sampai 2018 rata-rata stabil, menduduki peringkat 1 tiap tahunnya kecuali untuk tahun 2015 berada pada peringkat 2. Hal ini mencerminkan Manajemen Bank Mandiri telah melakukan penerapan Good Corporate Governance yang secara umum Sangat Baik. Hal ini tercermin dari pemenuhan yang sangat memadai atas prinsip-prinsip Good Corporate Governance. Apabila terdapat kelemahan dalam penerapan prinsip Good Corporate Governance, maka secara umum kelemahan tersebut tidak signifikan dan dapat segera dilakukan perbaikan oleh manajemen Bank Mandiri. Nilai komposit Bank BNI dari tahun 2014 sampai 2018 stabil pada peringkat 2 dengan predikat baik. Hal ini menunjukkan Manajemen Bank telah melakukan penerapan Good Corporate Governance yang secara umum baik. Hal ini tercermin dari 
Marissa Putriana dan Susi Artati, Analisis Perbandingan Tingkat Kesehatan Bank dengan Menggunakan Pendekatan RGEC (Studi pada PT. Bank Mandiri (Persero), Tbk dan PT. Bank Negara Indonesia (Persero), Tbk Periode 2014-2018)

pemenuhan yang memadai atas prinsip Tata Kelola. Dalam hal terdapat kelemahan penerapan prinsip Tata Kelola, secara umum kelemahan tersebut kurang signifikan dan dapat diselesaikan dengan tindakan normal oleh Manajemen Bank BNI.

\section{c. $\quad$ Earning (Rentabilitas) \\ Return on Assets (ROA)}

Return on Assets (ROA) adalah rasio untuk mengukur kemampuan bank menghasilkan laba dengan menggunakan asetnya. Nilai ROA bank mandiri dan bank BNI dari tahun 2014 - 2018 dapa dilihat pada tabel 4 berikut:

Tabel 4.

Rasio Return on Assets (ROA)

\begin{tabular}{|c|c|c|c|c|c|c|c|}
\hline \multirow[t]{2}{*}{ Tahun } & \multicolumn{3}{|c|}{ Bank Mandiri } & \multirow[t]{2}{*}{ Tahun } & \multicolumn{3}{|c|}{ Bank BNI } \\
\hline & ROA (\%) & Peringkat & Predikat & & $\operatorname{ROA}(\%)$ & Peringkat & Predikat \\
\hline 2014 & 3,57 & 1 & Sangat Sehat & 2014 & 3,5 & 1 & Sangat sehat \\
\hline 2015 & 3,15 & 1 & Sangat Sehat & 2015 & 2,6 & 1 & Sangat sehat \\
\hline 2016 & 1,95 & 1 & Sangat Sehat & 2016 & 2,7 & 1 & Sangat sehat \\
\hline 2017 & 2,72 & 1 & Sangat Sehat & 2017 & 2,7 & 1 & Sangat sehat \\
\hline 2018 & 3,17 & 1 & Sangat Sehat & 2018 & 2,8 & 1 & Sangat sehat \\
\hline
\end{tabular}

Sumber: data olahan

Berdasarkan Tabel 4 di atas dapat diketahui pada tahun 2014 sampai 2018 rasio ROA Bank Mandiri mengalami penurunan dan kenaikan, dan memiliki predikat sangat sehat. Nilai ROA yang dimiliki dari tahun 2014 hingga 2018 berurutan yaitu 3,57\%, 3,15\%, 1,95\%, 2,72\%, 3,17\%. Nilai ROA yang ditunjukkan memiliki nilai di atas 1,5\% menandakan bahwa semakin baik kualitas aktiva bank Mandiri. Sedangkan Bank BNI memiliki nilai ROA yang relatif stabil dengan predikat sangat sehat. Nilai ROA bank BNI dari tahun 2014 hingga 2018 yaitu 3,5\%, 2,6\%, 2,7\%, 2,7\%, 2,8\%. Nilai ROA di atas $2 \%$ menandakan bahwa semakin baiknya kualitas aktiva Bank BNI. Nilai ROA yang dimiliki antar Bank Mandiri dan Bank BNI saling bersaing. Pada tahun 2014 nilai ROA Bank Mandiri dan Bank BNI sama yaitu, 3,5\%. Pada 2015 dan 2018 nilai ROA Bank Mandiri lebih besar dibanding Bank BNI, pada tahun 2016 dan 2017 ROA Bank Mandiri lebih kecil dibanding Bank BNI. Semakin besar nilai ROA menunjukkan semakin besar tingkat keuntungan yang dicapai bank sehingga kemungkinan dalam kondisi tidak sehat semakin kecil.

\section{Net Interest Margin (NIM)}

Tabel 5

Net Interest Margin (NIM)

\begin{tabular}{|c|c|c|c|c|c|c|c|}
\hline Tahun & NIM (\%) & $\begin{array}{l}\text { Bank Mandiri } \\
\text { Peringkat }\end{array}$ & Predikat & Tahun & NIM (\%) & $\begin{array}{c}\text { Bank BNI } \\
\text { Peringkat }\end{array}$ & Predikat \\
\hline 2014 & 5,94 & 1 & Sangat Sehat & 2014 & 6,2 & 1 & Sangat Sehat \\
\hline 2015 & 5,90 & 1 & Sangat Sehat & 2015 & 6,4 & 1 & Sangat Sehat \\
\hline 2016 & 6,29 & 1 & Sangat Sehat & 2016 & 6,2 & 1 & Sangat Sehat \\
\hline 2017 & 5,63 & 1 & Sangat Sehat & 2017 & 5,5 & 1 & Sangat Sehat \\
\hline 2018 & 5,52 & 1 & Sangat Sehat & 2018 & 5,3 & 1 & Sangat Sehat \\
\hline
\end{tabular}

Sumber: data olahan

Berdasarkan tabel 5, pada tahun 2014 dan 2015, Bank BNI memiliki nilai NIM yang lebih tinggi yaitu, 6,2\% dan 6,4\% sedangkan NIM Bank Mandiri sebesar 5,94\% dan 5,9\%. Tahun 2016 Bank Mandiri dan Bank BNI memiliki nilai NIM yang hampir sama, Bank Mandiri memiliki nilai 6,29\% dan Bank BNI sebesar 6,2\%. Tahun 2017 dan 2018 NIM kedua Bank mengalami penurunan, NIM Bank Mandiri lebih unggul sedikit dengan nilai sebesar 5,63\% dan 5,52\%, sedangkan NIM Bank BNI 5,5\% dan 5,53\%. Tabel 5 juga dapat dilihat Bank Mandiri dan Bank BNI berada pada peringkat satu dari tahun 2014 sampai 2018 dengan kategori sangat sehat (NIM > 3\%). Hal ini menunjukkan baik itu Bank Mandiri maupun Bank BNI 
Marissa Putriana dan Susi Artati, Analisis Perbandingan Tingkat Kesehatan Bank dengan Menggunakan Pendekatan RGEC (Studi pada PT. Bank Mandiri (Persero), Tbk dan PT. Bank Negara Indonesia (Persero), Tbk Periode 2014-2018)

memiliki kemapuan sangat baik dalam mengelolah aktiva produktif yang dimiliki untuk memaksimalkan pendapatan bunga bersih.

\section{d. Capital (Permodalan)}

Analisis fakor permodalan dengan menghitung rasio kecukupan yaitu Capital Adequacy Ratio (CAR), merupakan perbandingan antara jumlah modal bank terhadap aktiva tertimbang menuru risiko (ATMR).

Tabel 6

Capital Adequacy Ratio (CAR)

\begin{tabular}{|c|c|c|c|c|c|c|c|}
\hline \multirow{2}{*}{ Tahun } & \multicolumn{3}{|c|}{ Bank Mandiri } & \multirow{2}{*}{ Tahun } & \multicolumn{3}{|c|}{ Bank BNI } \\
\hline & CAR $(\%)$ & Peringkat & Predikat & & $\operatorname{CAR}(\%)$ & Peringkat & Predikat \\
\hline 2014 & 16,6 & 1 & Sangat Sehat & 2014 & 16,2 & 1 & Sangat Sehat \\
\hline 2015 & 18,6 & 1 & Sangat Sehat & 2015 & 19,5 & 1 & Sangat Sehat \\
\hline 2016 & 21,36 & 1 & Sangat Sehat & 2016 & 19,4 & 1 & Sangat Sehat \\
\hline 2017 & 21,64 & 1 & Sangat Sehat & 2017 & 19,3 & 1 & Sangat Sehat \\
\hline 2018 & 20,96 & 1 & Sangat Sehat & 2018 & 18,5 & 1 & Sangat Sehat \\
\hline
\end{tabular}

Sumber: data olahan

Berdasarkan Tabel 6 di atas dapat diketahui bahwa Bank Mandiri pada tahun 2014 sampai 2018 memiliki rasio CAR secara garis besar stabil. Rata-rata nilai CAR tahun 2014 sampai 2018 dalam predikat sangat sehat. Artinya, bahwa Bank Mandiri memiliki modal yang kuat dan bisa mengatasi jika bank mengalami kerugian. Nilai CAR terendah terjadi pada tahun 2014, yaitu 16,6 \% dan nilai CAR yang tertinggi terjadi pada tahun 2017, yaitu 21,46\%. Sedangkan tahun 2015 nilai CAR Bank BNI mengalami kenaikan, dan mengalami penurunan pada tahun 2016 hingga 2018. Namun nilai CAR relatif stabil dengan predikat sangat sehat, nilai terendah pada tahun 2014, yaitu 16,2\% dan tertinggi pada tahun 2015 sebesar 19,5\%. BNI memliki CAR lebih besar dari $12 \%$ dan sudah melebihi standar minimal Bank Indonesia yaitu sebesar 9\%, hal ini menunjukkan bahwa Bank BNI memiliki tingkat kecukupan modal yang baik dengan predikat sangat sehat.

\section{SIMPULAN}

Berdasarkan tujuan penelitian dan pembahasan yang telah dipaparkan diatas, maka dapat ditarik kesimpulan sebagai berikut:

1. Tingkat kesehatan Bank Mandiri dan BNI tahun 2014-2018 secara keseluruhan adalah sehat.

2. Penilaian Risk Profile (Profil Risiko) yang menggunakan risiko kredit (NPL) pada Bank Mandiri dan bank BNI memperoleh predikat sehat. Penilaian risiko likuiditas (LDR) Bank Mandiri dan Bank BNI memperoleh predikat cukup sehat .

3. Penilaian Good Corporate Governance (GCG) berdasarkan Self Assessment perusahaan pada Bank Mandiri memperoleh predikat Sangat Baik atau Sangat Sehat sedangkan Bank BNI memperoleh predikat Baik.

4. Penilaian Earnings (Rentabilitas), dari analisis rasio ROA dan NIM, Bank Mandiri dan Bank BNI memperoleh predikat sangat sehat.

5. Penilaian Capital (Permodalan) berdasarkan analisis nilai CAR, Bank Mandiri dan Bank BNI memperoleh predikat sangat sehat.

\section{DAFTAR PUSTAKA}

Bank Indonesia. 2011. Peraturan Bank Indonesia Nomor. 13/1/PBI/2011 tentang Prosedur dan Mekanisme Penilaian Tingkat Kesehatan Bank.

Bank Indonesia. 2011. Surat Edaran Bank Indonesia Nomor. 13/24/DPNP/2011 pada tanggal 25 oktober 2011 tentang Prosedur dan Penilaian Tingkat Kesehatan Bank Umum.

Ismail. 2013. Manajemen Perbankan. Kencana Prenada Media Group Jakarta. 
Kartika, Ayu. 2016. Analisis Perbandingan Tingkat Kesehatan Bank antara PT. Bank Mandiri (Persero),tbk dan PT. Bank Central Asia,Tbk menggunalan metode RGEC periode 2011-2013. Jurnal Ekonomi Bisnis Vol. 21 No. 2, Agustus 2016. FE Universitas Gunadarma.

Kasmir. 2014. Analisis Laporan Keuangan. PT. Raja Grafindo, Depok.

Simorangkir, 2004. Pengantar Lembaga Keuangan Bank Ikatan Akuntan Indonesia. 2007. Pernyataan Standar Akutansi Keuangan No.31 Mengenai Akuntansi Perbankan (revisi tahun 2000)dan Nonbank. Ghalia Indonesia, Jakarta. 